\title{
Children under 15 years old of road risk in Ouagadougou (Burkina Faso)
}

Manhamady Ouedraogo and Emmanuel Bonnet

\section{(2) OpenEdition}

Journals

Electronic version

URL: http://journals.openedition.org/rfst/827

DOI: $10.4000 /$ rfst. 827

ISSN: 2492-3672

Publisher

Espaces et SOciétés (UMR 6590)

Electronic reference

Manhamady Ouedraogo and Emmanuel Bonnet, "Children under 15 years old of road risk in Ouagadougou (Burkina Faso)", Revue francophone sur la santé et les territoires [Online], Mobility, Transports and Health, Online since 06 June 2019, connection on 06 April 2021. URL: http:// journals.openedition.org/rfst/827 ; DOI: https://doi.org/10.4000/rfst.827

This text was automatically generated on 6 April 2021.

\section{c) (†)}

La Revue francophone sur la santé et les territoires est mise à disposition selon les termes de la Licence Creative Commons Attribution - Pas d'Utilisation Commerciale - Partage dans les Mêmes Conditions 4.0 International. 


\title{
Children under 15 years old of road risk in Ouagadougou (Burkina Faso)
}

\author{
Manhamady Ouedraogo and Emmanuel Bonnet
}

1 Road accidents among children are now a major public health problem worldwide. According to a WHO report (2015), 186300 children die on the roads worldwide, and the most at risk of death live in low- and middle-income countries (WHO 2015). The subSaharan African region has the highest number of road accidents among children with $32 \%$ of deaths (Li, Alonge, and Hyder 2016). They are the most vulnerable to road crash risk because of their physical and cognitive attributes still in development (Cloutier and Apparicio 2008). Ouagadougou, the capital of Burkina Faso, has experienced, and continues to experience, rapid spatial dynamics. The commuting between the periphery and the city centre is very important and generates dense traffic. These mobilities, through the different modes of transport, represent a risk of road accidents for vulnerable users such as children. Little research has been done on children's exposure to road crash risks. The objective is to analyse the individual characteristics of children and the residential areas urban environment in relation to road accident risk among children under 15 years of age in their daily activities (play and going to and from school) in Ouagadougou. This research aims to understand their vulnerability in their daily mobility on the Ouagadougou territory.

2 We conducted a study in 12 elementary schools in the city of Ouagadougou between April and May 2017 with students under 15 years of age in the first (CE1) and second year (CE2) of elementary classes, and in the first year (CM1) and second year (CM2) of middle classes. The surveyed schools were randomly selected by district. Authorization was requested and granted from the Ministry of National Education and Literacy regional directorate for a survey of students in these schools. Students were interviewed individually using a questionnaire. Each student randomly selected came out of the classroom in turn to answer different questions. Collected data were entered into the Sphinx data processing and analysis software. The data analysis was performed on XLSTAT 2018 software. As for the qualitative data collection method, it is based on 
direct observation technique including a form on the different types of facilities around schools.

3 More than 500 children (523) were surveyed. Boys (31\%) are more involved in accidents than girls (25\%). State-employed fathers (41\%) and not working fathers (33\%) have more children involved in road accidents. At the mother level, it is students (33\%) and state employees (31\%) who have more children involved in accidents. Children residing in unplanned areas $(36 \%)$ are more involved in road accidents than those in unplanned areas (18\%). Children are more likely to be involved in an accident if they prefer to play on the street in front of the housing yard (31\%) and if they prefer to play inside the housing yard (30\%). Nearly $28 \%$ of children have already had a road accident and $70 \%$ of them have been injured. Facilities around schools to reduce the risk of children being involved in road accidents are non-existent. Thus, in all the schools surveyed, no speed bumps were built to reduce the speeds of motorized users, nor were there any warning signs to alert road users of the presence of a school. In addition, schools near major roads (main roads) do not have crossing guards to help children cross. It is important to reduce the risk of accidents among children by providing facilities around schools and in densely populated areas.

These results reveal a high exposure of children to accident risks in subdivided areas compared to un-divided areas in Ouagadougou. Monitoring children during their street play and planning policies that take children's road safety into account are necessary to reduce the risk.

Table 1. Children involved in accidents by socio-demographic and socio-territorial characteristics

Table $\mathrm{N}^{\circ} 1$ : Children involved in accidents by socio-demographic and socio-territorial characteristics

\begin{tabular}{lcc}
\hline & Number of surveyed & $\begin{array}{c}\text { Number of children } \\
\text { involved in an } \\
\text { accident }\end{array}$ \\
\hline Gender & 271 & $69(25 \%)$ \\
Female & 252 & $80(31 \%)$ \\
Male & 73 & $21(29 \%)$ \\
\hline Father & 129 & $53(41 \%)$ \\
Farmer/Cultivator/Breeder & 159 & $36(23 \%)$ \\
State employee & 22 & $6(27 \%)$ \\
Employer/worker & 137 & $32(23 \%)$ \\
Don't know & 3 & $1(33 \%)$ \\
Trader, travelling trader & & \\
Does not work & 9 & $1(11 \%)$ \\
\hline Mother & 65 & $20(31 \%)$ \\
Farmer/Cultivator/Breeder & 6 & $2(33 \%)$ \\
State employee & 51 & $12(24 \%)$ \\
Student & 16 & $5(31 \%)$ \\
Employer/worker & 1 & $0(0 \%)$ \\
Don't know & 182 & $53(29 \%)$ \\
Domestic service & 193 & $56(29 \%)$ \\
Trader, travelling trader & & $112(\mathbf{3 6} \%)$ \\
Does not work/household & 313 & $37(\mathbf{1 8} \%)$ \\
\hline Residential area & 210 & $77(30 \%)$ \\
Allotted area & & $40(31 \%)$ \\
Unplanned area & 257 & $24(24 \%)$ \\
\hline Preferred play area & 129 & $8(23 \%)$ \\
In the courtyard & 102 & \\
In the street in front of the courtyard & 35 & \\
On a field & & \\
Other & between the residential area and the \\
The chi-square test is only very significant & \\
involvement of children in road accidents with p<0.0001 & \\
& & \\
\hline
\end{tabular}




\section{BIBLIOGRAPHY}

Cloutier, M.-S., \& Apparicio, P. (2008). L'environnement autour des écoles a-t-il un impact sur le risque routier impliquant des enfants piétons à Montréal ? Apport de la régression de Poisson géographiquement pondérée. Territoire en mouvement Revue de géographie et aménagement. Territory in movement Journal of geography and planning, (1), 25-38.

Li, Q., Alonge, O., \& Hyder, A. A. (2016). Children and road traffic injuries: can't the world do better? Archives of Disease in Childhood, 101 (11), 1063- 1070.

INDEX

Geographical index: Ouagadougou, Burkina Faso

Keywords: road accident, road risk, childrens

\section{AUTHORS}

\section{MANHAMADY OUEDRAOGO}

Doctorant, UMR IDEES CNRS, Caen, France

\section{EMMANUEL BONNET}

Chargé de recherche, UMI Résiliences, IRD, Bondy, France 